\title{
ACOUSTIC SCHWANNOMA WITH INTRATUMORAL HEMORRHAGE - REPORT OF AN UNUSUAL COMPLICATION
}

\author{
Letícia Rocha Magalhães, Larissa Gasquez Magnesi, Gisele Alborghetti Nai \\ Universidade do Oeste Paulista - UNOESTE, Faculdade de Medicina, Presidente Prudente, SP. E-mail: \\ patologia@unoeste.br
}

\begin{abstract}
Acoustic Schwannoma is a benign neoplasm of the 8th cranial nerve pair, and accounts for $8-10 \%$ of all intracranial tumors. Intratumoral haemorrhage is unusual in these tumors and can lead to hydrocephalus or aggravate a preexisting condition. This paper reports a case of acoustic Schwannoma in a child with complication with intratumoral hemorrhage that lead patient to death. Female patient, 9 years old, presented anacusis on the right, sudden, progressing with vomiting, intense headache and vertigo. Magnetic resonance imaging of the skull showed expansive lesion in the cistern of the right cerebellar angle, with content inside the internal auditory canal, with compression of the adjacent brain stem. The diagnostic hypothesis was acoustic Schwannoma. It progressed with worsening of headache, initially controlled with medication and later loss of consciousness. Computed tomography of the skull revealed an expansive lesion in the cistern of the right cerebellar angle with signs of bleeding with extension to the ventricular system. External ventricular shunt was performed, but the patient evolved with several complications, septic shock and death. Intratumoral hemorrhage in the acoustic Schwannoma is a rare event, but its occurrence worsens the clinical picture and may lead to death of the patients due to intracranial hypertension.
\end{abstract}

Keywords: cranial nerve neoplasms, neuroma, acoustic, hydrocephalus, intracranial pressure, diagnostic imaging.

\section{SCHWANNOMA DO ACÚSTICO COM HEMORRAGIA INTRATUMORAL - RELATO DE UMA COMPLICAÇÃO INCOMUM}

\section{RESUMO}

O Schwannoma do acústico é uma neoplasia benigna do 80 par nervoso craniano, e corresponde a 8-10\% de todos os tumores intracranianos. Hemorragia intratumorais são raras nestes tumores e podem acarretar em hidrocefalia ou agravar um quadro preexistente. Este trabalho relata um caso de Schwannoma acústico em criança com complicação com hemorragia intratumoral que levou o paciente ao óbito. Paciente feminina, 9 anos de idade, apresentou anacusia à direita, súbita, progredindo com vômito, cefaleia intensa e vertigem. A ressonância magnética do crânio mostrou lesão expansiva na cisterna do ângulo pontocerebelar direito, com conteúdo no interior do conduto auditivo interno, com compressão do tronco cerebral adjacente. A hipótese diagnóstica foi de Schwannoma do acústico. Evoluiu com piora da cefaleia, inicialmente controlada com medicação e posterior perda de consciência. A tomografia computadorizada de crânio mostrou lesão expansiva na cisterna do ângulo ponto-cerebelar direito com sinais de hemorragia com extensão para o sistema ventricular. Realizou-se derivação ventricular externa, porém a paciente evoluiu com diversas complicações, choque séptico e óbito. A hemorragia intratumoral no Schwannoma do acústico é um evento raro, porém sua ocorrência agrava o quadro clínico, podendo acarretar em óbito dos pacientes por hipertensão intracraniana.

Palavras-chave: neoplasias dos nervos cranianos, neuroma acústico, hidrocefalia, pressão intracraniana, diagnóstico por imagem. 


\section{INTRODUCTION}

Acoustic or vestibular Schwannoma is a neuroectodermal type tumor that develops from the Schwann cells located in the cochlear vestibular nerve, has a benign character and slow growth. Its occurrence is more frequent in young individuals, being rare in pediatric patients ${ }^{1}$.

This tumor accounts for about $6-7 \%$ of all intracranial tumors, with an annual incidence of about 1: $100,000^{2}$. Main manifestation is the decrease in auditory acuity or unilateral anacusis due to impairment of the VIII cranial nerve. Other common complaints associated with this pathology are the presence of tinnitus, vertigo, headache and facial numbness. The appearance of other different symptoms may be associated with the compression of other structures such as the other cranial nerves, cerebellum and brainstem ${ }^{3}$. Intratumoral haemorrhages related to acoustic Schwannoma are extremely rare ${ }^{4}$.

There are many treatment options for Schwannomas, such as observation with followup imaging, radiosurgery and microsurgery. However, the management of these lesions is widely debated, due to the large number of different tumor volumes and growth patterns that can be observed in Schwannomas ${ }^{1}$.

This paper reports a case of acoustic Schwannoma that occurred in a child with intratumoral hemorrhage, a rare complication of this neoplasm and that may lead to death as in the case reported.

\section{CASE REPORT}

A 9-year-old female patient, a highperformance athlete (ornamental jumps since 2 years ago), presented anacusis on the right, with no apparent triggering factor. The mother said that the daughter had moments of headache and seasickness in previous years, however were not intense and most of the time when she was inside the moving car.

During the clinical investigation of the anacusis, the patient began to present vomiting, intense headache and vertigo, being referred to the hospital for suspicion of intracranial hypertension. Posteriorly and during the internment, the child also said that after the training, she needed to "open her legs" to get balance to comb the hair.

At the entrance physical examination, she presents with a good articulation of speech. A magnetic resonance imaging (MRI) of the skull was performed showing an expansive lesion in the cistern of the right cerebellar angle, with content inside the internal auditory canal, measuring $37 \times 30 \times 26 \mathrm{~mm}$, determining compression of the adjacent brain stem associated with deviation / compression of the fourth ventricle (Figure 1).

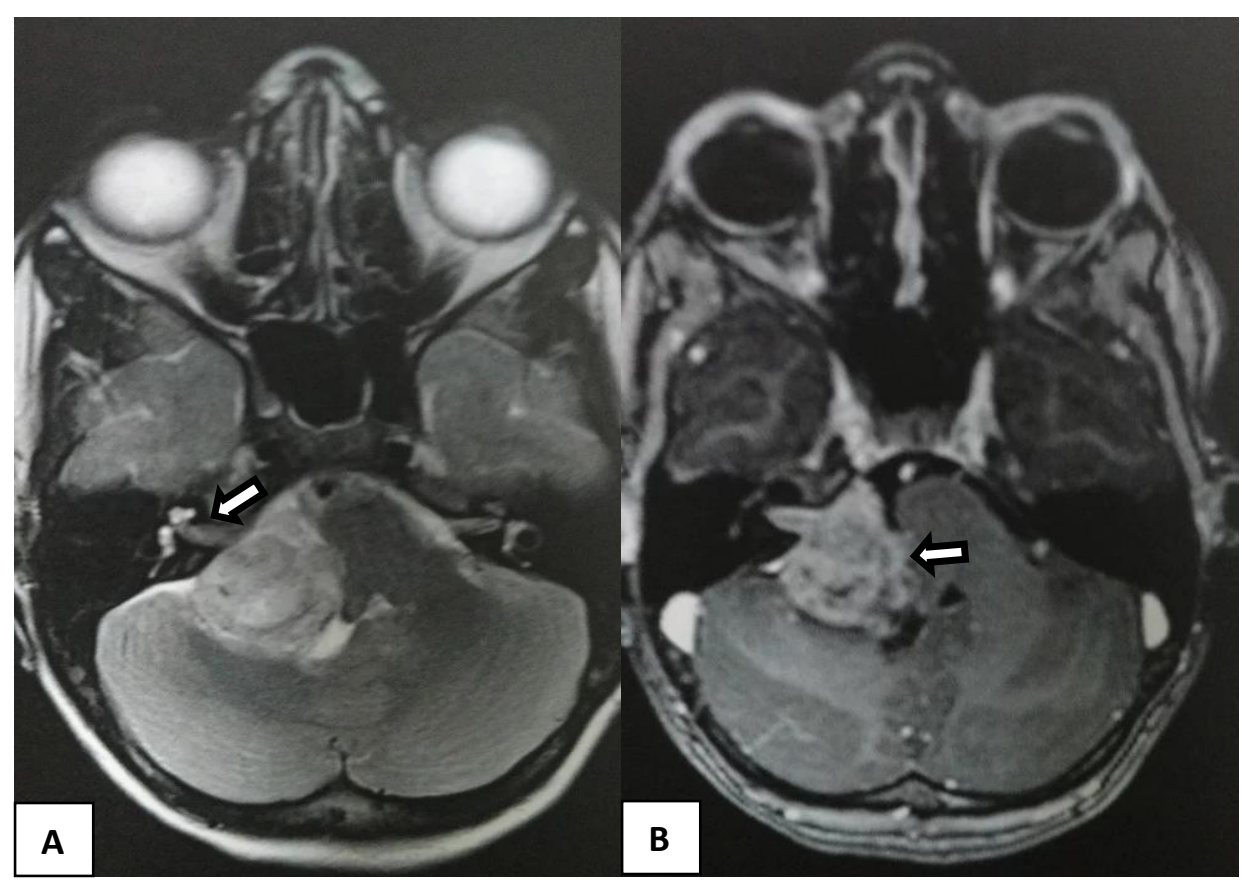

Figure 1. Magnetic resonance T2 image of the skull. A - Extra-axial expansive lesion in the cistern at the right cerebellar angle with a component inside the adjacent internal auditory canal (arrow). B - Lesion determining mass effect, with compression of the brainstem and adjacent cerebellar hemisphere (arrow). 
The digital electroencephalogram with cerebral mapping showed a moderate disorganization of brain electrical activity. The MRI of the cervical, dorsal and lumbosacral spine did not show any apparent changes. The diagnostic hypothesis was acoustic Schwannoma. The patient had no history of neurofibromas, and on physical examination, she presented only a single brownish-macular type lesion on the skin of the arm.

Headache was controlled with medication, but vomiting persisted. Four days after hospitalization, the patient had an intense episode of headache, which was medicated, but progressed, with loss of consciousness, desaturation and an important oscillation of blood pressure. MRI of the skull was performed, showing hypoattenuation of the thalamus and corpus striatum, especially the right one (with the main diagnostic hypothesis of hypoxic-ischemic damage); diffuse erasure of the cortical grooves, fissures and encephalic cisterns and of the ventricular system; an expansion lesion in the cistern of the right cerebellar angle with signs of bleeding with extension to the ventricular system, causing hydrocephalus and determining compression of the brainstem and the fourth ventricle.

The patient was referred to the surgical center, in coma, and an external ventricular shunt was performed. The patient evolved with pneumothorax and pneumonia that were controlled. Tracheostomy was performed and she required blood transfusions due to a drop in platelet levels, as well as regularization of sodium and glycemia levels. She evolved to septic shock and death after 47 days of intratumoral hemorrhage.

The patient's mother signed the informed consent form authorizing the publication of the case. This report was approved by the Research Ethics Committee of Universidade do Oeste Paulista (CAAE no 83204218.5.0000.5515).

\section{DISCUSSION}

Acoustic Schwannomas have a higher prevalence in the fifth and sixth decades of life and when they occur in children are more common in the context of von Recklinghausen disease, although there are cases described not associated with neurofibromatosis in this age group ${ }^{5}$. In the present case, the patient was 9 years old and although she had a "café au lait" spot, she had no other characteristics of neurofibromatosis.

Sudden anacusis is classically the first symptom of acoustic Schwannomas ${ }^{5}$. Many cases published in the literature ${ }^{6-9}$, including the present case, reported hearing loss as the first symptom. The patient of the present report besides presenting anacusis, presented vomiting, intense headache and vertigo, which shows the occurrence of vestibular symptoms of imbalance, as well as intracranial hypertension. The patient's hydrocephalus picture was aggravated by intratumoral hemorrhage with extension to the ventricular system, which contributed to the aggravation of the symptomatology and evolution to coma.

Intratumoral hemorrhage in the acoustic Schwannoma is considered to be a rare complication and its recurrence is even more uncommon ${ }^{6}$. There are several theories for the pathogenesis of bleeding. Some of the explanations are vascular proliferation followed by necrosis and invasion of the vascular wall by tumor cells ${ }^{6}$. There are different risk factors for intratumoral hemorrhage in acoustic Schwannoma, among them: tumor size $(>2 \mathrm{~cm})$, rapid tumor growth, abnormal vasculature and radiosurgery. In addition, there are reports that the use of anticoagulants, methotrexate, cocaine and trauma may cause intratumoral hemorrhage in these tumors. But tumor size and abnormal vasculature composition appear to be the most important factors ${ }^{7}$.

In the study by Niknafs et $\mathrm{al}^{4}$, where the authors selected 39 cases of acoustic Schwannomas with hemorrhage, described in 18 published articles, the mean age of patients and tumor size in hemorrhagic cases of acoustic Schwannomas did not differ significantly from those non-hemorrhagic cases. The main initial symptom of acoustic Schwannomas with hemorrhage was dysfunction of the facial nerve, which occurred in $33.3 \%$ of the cases. Abnormality of tumor-associated vasculature has been observed histologically in many cases. Death occurred more frequently in hemorrhagic acoustic Schwannomas (10\%) than in nonhemorrhagic acoustic Schwannomas $(0.2 \%)^{4}$.

There are case reports in the literature that have reported repeated intratumoral hemorrhage $e^{6-10}$. These were relatively large 
tumors with abnormal vasculature. The change in tumor size can be attributed to microhemorrhages, which lead to its expansion ${ }^{10}$. In addition, all these patients reported sudden headache at the time of bleeding ${ }^{6-10}$. In the present case, the patient had a single episode and the apparent risk factor for intratumoral hemorrhage was tumor size $(3.7 \mathrm{~cm}$ on the largest axis). In our case, vasculature abnormality was not observed on radiological examinations, and as the patient was not submitted to surgery, this alteration cannot be analyzed histologically. Although our patient had not multiple episodes of hemorrhage, she also experienced intense and sudden headache in the occurrence of intratumoral hemorrhage.

Acoustic Schwannomas can be classified according to the size of the tumor according to the Koos classification ${ }^{11}$ in: Grade । (intracanalicular tumor); Grade II (small tumor projecting at cerebellar angle, up to $2 \mathrm{~cm}$ ); Grade III (tumor that occupies the cistern of the cerebellar angle, without displacement of the brainstem, with up to $3 \mathrm{~cm}$ ); and Grade IV (large tumor with displacement of the brainstem or cranial nerves, greater than $3 \mathrm{~cm}$ ). The patient of the present case had a Grade IV tumor (measuring $3.7 \mathrm{~cm}$ on the largest axis and brainstem displacement).

The treatment possibilities for acoustic Schwannoma are observation, microsurgery or radiosurgery. The treatment is selected according to the characteristics of the tumor and the patient ${ }^{12}$. Large tumors (greater than $3 \mathrm{~cm}$ in any dimension) have a surgical indication ${ }^{13}$. In the present report, the patient was to undergo surgery for removal of the tumor, but in the face of hydrocephalus caused by intratumoral hemorrhage, which resulted in intracranial hypertension, ventricular shunt was chosen, in an attempt to improve hydrocephalus for subsequent surgery to remove the tumor, but the patient evolves with other complications and death.

This case report highlights a rare complication of the acoustic Schwannoma, intratumoral hemorrhage, which is more described in adult patients and greatly increases the possibility of patients' death $10.0 \%$ in hemorrhagic Schwannoma and $0.2 \%$ in nonhemorrhagic Schwannoma) $)^{4}$. However, one of the limitations of this case report is the fact that, due to the severity of the patient's clinical condition, it was not possible to perform surgery to remove the tumor, which made histopathological analysis impossible for Schwannoma's diagnostic confirmation and evaluation of possible vascular alterations, the that could explain the intratumoral hemorrhage.

Further studies are needed to clarify the causes of intratumoral hemorrhage associated with acoustic Schwannoma, in order to enable its early detection and prevention of death in these patients.

\section{CONCLUSION}

Although it is a rare event, the hypothesis of intratumoral hemorrhage in the acoustic Schwannoma should be considered in the worsening of the patient's clinical condition, even in children, as it can lead to death of these patients due to intracranial hypertension.

\section{ACKNOWLEDGMENTS}

This manuscript is dedicated to the patient and her mother.

\section{CONFLICTS OF INTEREST}

The authors declare that there is no potential conflict of interest that could interfere with the impartiality of this scientific work.

\section{REFERENCES}

1. Wang J, Xu Y, Lei T and Zeng L. Treatment decision-making for sporadic small vestibular schwannoma in a pediatric patient: A case report and literature review. Oncol Lett [Internet]. 2015 March [cited 2020 Apr 15]; 9(5): 2371-2373, $2015 . \quad$ Available from: https://doi.org/10.3892/ol.2015.3058

2. Hassepass F, Bulla Sb, Aschendorff A, Maier W. Vestibularis schwannom: Teil I: Epidemiologie und Diagnostik. HNO [Internet]. 2012 August [cited 2020 Apr 15]. Available from: https://www.springermedizin.de/vestibularissch wannom/8034038 Accessed 2019 Dec 12.

3. Greene J, Al-Dhahir MA. Acoustic Neuroma. StatPearls [Internet]. 2010 August [cited 2019 Dec 12]. Available: https://www.ncbi.nlm.nih.gov/books/NBK470177

4. Niknafs YS, Wang AC, Than KD, Etame AB, Thompson BG, Sullivan SE. Hemorrhagic vestibular schwannoma: review of the literature. World Neurosurg [Internet] 2014 
November [cited 2020 Apr 15]; 82(5):751-6. Available from: https://doi.org/10.1016/i.wneu.2013.02.069

5. Nai GA, Ferrari AF, Naufal RF, Prates MA. Shwannoma unilateral do acústico em criança sem associação com neurofibromatose. Arq Bras Neurocir [Internet] 2011 [cited 2020 Jan 23]; 30(4): 182-185. Available from: https://doi.org/10.1055/s-0038-1625636

6. Banaama S, Overbeeke JV, Temel Y. An unusual case of repeated intracranial hemorrhage in vestibular schwannoma. Surg Neurol Int [Internet] 2016 November [cited 2019 Dec 12]; 7(37):S869-S871. Available from: https://doi.org/10.4103/2152-7806.194494

7. Kim SH, Youm JY, Song SH, Kim Y, Song KS. Vestibular schwannoma with repeated intratumoral hemorrhage. Clin Neurol Neurosurg [Internet] 1998 March November [cited 2019 Dec 12]; 100(1):68-74. Available from: https://doi.org/10.1016/S0303-8467(98)00002-X

8. Mandl ES, Vandertop WP, Meijer OW, Peerdeman SM. Imaging-documented repeated intratumoral hemorrhage in vestibular schwannoma: A case report. Acta Neurochir [Internet] 2009 March [cited 2019 Dec 12]; 151:1325-1327. Available from: https://doi.org/10.1007/s00701-009-0213-9

9. Sughrue $M E$, Kaur R, Kane AJ, Rutkowski MJ, Yang I, Pitts LH, Tihan T, Parsa AT: Intratumoral hemorrhage and fibrosis in vestibular schwannoma. A possible mechanism for hearing loss: Clinical article.J Neurosurg [Internet] 2011 february [cited 2019 Dec 12]; 114(2):386-93. Available from: https://doi.org/10.3171/2010.5.JNS10256

10. Takeuchi S, Nawashiro $\mathrm{H}$, Otani N, Sakakibara F, Nagatani K, Wada K, et al. Vestibular schwannoma with repeated intratumoral hemorrhage. J Clin Neurosci [Internet] 2012 September [cited 2020 Mar 12]; 19(9):1305-1307. Available from: https://doi.org/10.1016/j.jocn.2011.11.028

11. Koos WT, Day JD, Matula C, Levy DI. Neurotopographic considerations in the microsurgical treatment of small acoustic neurinomas. J Neurosurg [Internet] 1998 March; [cited 2020 Apr 15] 88(3):506-12. Available from: https://doi.org/10.3171/jns.1998.88.3.0506

12. Arribas L, Chust ML, Menéndez $A$, Arana $\mathrm{E}$, Vendrell JB, Crispín V, et al. Non-surgical treatment of vestibular schwannoma. Acta Otorrinolaringol Esp [Internet] 2015 July-Augusty; [cited 2019 Dec 12] 66(4):185-91. Available from: https://doi.org/10.1016/i.otoeng.2014.08.002

13. Yang HC, Kano $H$, Awan NR, Lunsford LD, Niranjan A, Flickinger JC, et al. Gamma knife radiosurgery for larger-volume vestibular schwannomas. J Neurosurg [Internet] 2011 March; [cited 2020 Apr 15] 114(3):801-7. Available from: https://doi.org/10.3171/2010.8.JNS10674 